Psychology of Language and Communication 2017, Vol. 21, No. 1

DE DE GRUYTER

OPEN

DOI: $10.1515 /$ plc-2017-0013

KATARZYNA KONOPKA ${ }^{1}$, EWA PISULA ${ }^{1}$, EMILIA ŁOJEK ${ }^{1}$, PIOTR FUDALEJ ${ }^{2}$

${ }^{1}$ University of Warsaw

${ }^{2}$ University of Bern, Palacký University Olomouc

\title{
METAPHOR COMPREHENSION AND INTERPRETATION IN CLEFT PALATE CHILDREN AGED 6-9
}

\begin{abstract}
The level of metaphor comprehension and interpretation was investigated in a sample of children with cleft palate (CP), aged 6;0-8;11, and healthy controls matched with age, sex, socioeconomic status, and IQ level. The Wechsler Intelligence Scale for Children - Revised (WISC-R) was used to evaluate the children's cognitive functioning, and the metaphor tests from a modified version of the Right Hemisphere Language Battery - Polish version (RHLB-PL) were used to assess comprehension of figurative language. The $\mathrm{CP}$ and control groups differed significantly in Verbal IQ values and in performance in the Vocabulary test, Comprehension test, Picture Metaphor Explanation test, and Written Metaphor Explanation test. In both metaphor explanation tests, children with CP gave fewer responses than controls. The results suggest no differences between children with $\mathrm{CP}$ and controls in understanding figurative language, although they point to weaker performance in communicating responses and producing statements in the $\mathrm{CP}$ children group.
\end{abstract}

Key words: cleft palate, metaphors, communicative competence, figurative language

\section{Introduction}

Cleft palate (CP) is the most frequent abnormality of face development and occurs when tissue in the mouth and nose area does not fuse properly (Dudkiewicz, 1997). On average, there is one case of CP per 700 live births (Wen \& Lu, 2015). This abnormality can occur in isolation (nonsyndromic CP accounts for $70 \%$ of cases) or in genetic syndromes (Jones, 1988). Children with

Address for correspondence: Ewa Pisula, Faculty of Psychology, University of Warsaw, Stawki 5/7, 00-183 Warsaw, Poland. E-mail: ewa.pisula@psych.uw.edu.pl 
CP have to contend with many difficulties in the early years of their life, involving both basic processes - breathing and eating - and articulation disorders, as well as some peculiar features of nonverbal expression (Pluta-Wojciechowska, 2010). In the first year of life, when dynamic changes in the speech apparatus, as well as development of brain structures connected with speech take place, these children undergo a complicated and harrowing surgical procedure. It leads to a halt in speech production prior to and after palatal surgery, which in turn is correlated with later speech production (Chapman, Hardin-Jones, \& Halter, 2003). All this creates special conditions in which CP children develop.

Preverbal behaviors occurring in a child's first year are significant in the subsequent development of speech and language (Warlaumont, Oller, Buder, Dale, \& Kozma, 2010). Researchers have found that delayed babbling can be a predictor of subsequent difficulties in speech development (Goldstein, Schwade, \& Bornstein, 2009), while early problems with vocalization can be expected to be followed by slower development of a child's vocabulary (Oller, Eilers, Neal, \& Schwartz, 1999; Stoel-Gammon, 2011). The preverbal stage of speech development plays a major role not only in phonological but also social and cognitive development. Sounds produced by a child serve interpersonal communication and also enable the child to learn about the world, turning it into an active partner in dialogues with other people (Kuhl \& Meltzoff, 1996; Vihman, 1993, 1996). Children with CP babble much less than their age-matched peers (Chapman, Hardin-Jones, Schulte, \& Halter, 2001). Therefore the question arises whether difficulties with producing sounds, and even with sucking, swallowing or breathing, which occur in $\mathrm{CP}$ children for anatomical and functional reasons, affect the level of linguistic and cognitive development at a later age.

So far, relevant research involving subjects with $\mathrm{CP}$ has not brought a clear answer. The fewest doubts are linked to articulation disorders, which occur more often especially in younger $\mathrm{CP}$ children (e.g., Brunnegård \& Lohmander, 2007). It has also been found that at preschool age, these children have a smaller vocabulary and that this applies, above all, to words starting with consonants that are hard for a given child to utter (Hardin-Jones \& Chapman, 2014). The results of research on CP children's cognitive development are less coherent. Some studies have shown no differences between these children and their typically developing peers (e.g., Collett, Leroux, \& Speltz, 2010; Collett, Keich Cloonan, Speltz, Anderka, \& Werler, 2012). Other researchers, however, have noted that the group with $\mathrm{CP}$ has a lower general intelligence level (e.g., Richman \& Nopoulos, 2009), verbal IQ (Conrad, Nopoulos, \& Dailey, 2009; Kuehn \& Moller, 2000), and also experience difficulties in learning to read and write (Chapman, 2011; Richman, Eliason, \& Lindgren, 1988; Richman, Wilgenbusch, \& Hall, 2005).

The level of linguistic development is of major importance for the psychological adjustment of children with CP (Feragen Særvold, Aukner, \& Stock, 2017). Furthermore, since speech production skills and language abilities are connected with reading skills (Chapman, 2011), they can affect school 
achievements and the further development of children with cleft palate. Problems with speech production could cause these children to attain a generally lower level of linguistic development compared to their peers, and to be less active in conversations (Frederickson, Chapman, \& Hardin-Jones, 2006). Therefore, it seems important to investigate different aspects of linguistic development of children with $\mathrm{CP}$, as this could be useful in focusing interventions on existing problems in this area. One aspect as yet unresearched in children with $\mathrm{CP}$ is the use of figurative language.

Understanding metaphors is considered to be an advanced form of linguistic development, requiring a certain level of cognitive functioning (cf. Davidson, 1978). Metaphor is a fundamental way of expressing new sense and creating meaning (cf. Dobrzyńska, 2012). It is also a manifestation of communicative competence, because it requires the interlocutor to understand the speaker's intention. Studies of children with language disorders show that one good predictor of metaphor comprehension is language skills, especially semantic skills, enabling the meaning of figurative expressions to be analyzed (Cain, Towse, \& Knight, 2009; Norbury, 2005). Hence, if the linguistic development of a child with CP is disturbed at an early developmental stage, this could have consequences for how the child understands and uses metaphors.

Children start understanding metaphors around four years of age (Happé \& Loth, 2002; Özçaliskan, 2005), although processes necessary for this skill to develop occur much sooner, including symbolic games (Leslie, 1994). At preschool age, children are already able to find metaphorical expressions for pictures they are shown (Kubicka, 2005). Understanding metaphors requires a certain amount of knowledge about objects and their properties, as well as skills to transfer this knowledge from one area to another, that is, reasoning through analogy (Bryan, 2007; Vosniadou \& Schommer, 1988). It is essential to understand the relations between classes of objects, and also their hierarchic order (Bjorklund, 2005). According to the classical theory of cognitive development of Piaget (1954), this corresponds to attaining the concrete operational stage. At this stage, at early school age (7-11 years), children can classify objects and understand the relations between them. Children at this age are ready to approach reality from different points of view (Bee, 2004; Białecka-Pikul, 2012). It is a period when articulative patterns have been mastered and speech is only being improved (Lobacz, 2005). Linguistic and communicative competence develops rapidly, including metaphor comprehension. Research results indicate that in this period, around 10 years of age, children understand figurative language (Cain et al., 2009; Qualls, O’Brien, Blood, \& Hammer, 2003).

It is interesting to see how metaphor comprehension in children can be affected by the form of presentation: pictorial versus verbal. Numerous studies have shown a picture-superiority effect in memory and learning (e.g., Curran \& Doyle, 2011; Defetyer, Russo \& McPartlin, 2009). However, no such effect was noticed by Kogan and Chadrow (1986) in the case of metaphor comprehension in 
children (from the second and fifth grades). Some metaphors presented verbally were even better understood, especially if their structure included the perceptual similarity of objects. Therefore, although the use of pictorial material might help children understand or memorize specific information, it could hinder the correct decoding of metaphorical meaning. On the other hand, if verbal solutions to a task in a metaphor test are given to children as yet unable to read fluently and understand what they have read, there are "performance limitations" involved (Białecka-Pikul, 2002). Subjects have to engage their operating memory and remember the responses presented to them, whereas in picture-based tests, they have the presented material before them the whole time. This could affect the results of measurements related to metaphor comprehension.

The level of metaphor comprehension could also be influenced by context. Some researchers believe it is the context precisely that gives metaphors their meaning (Weinrich, 1981). Others underline that metaphor comprehension in children takes place through analogy, by their referencing familiar situations (Biela, 1981), hence understanding figurative language could be connected with the amount of additional, contextual information.

The main aim of the present study was to investigate the understanding and interpretation of metaphors by children of early school age who had experienced motor difficulties in speech production in the first years of their lives as a result of a development defect (CP). The other question was how metaphors would be understood and explained depending on the type of presentation: pictorial versus verbal, and also on context.

\section{Method}

The study was part of a larger project on the cognitive functioning of children with CP at early school age (Konopka, 2017).

\section{Subjects}

The study involved two groups of children aged 6;0-8;11 within the intellectual norm (IQ>90). Group one comprised children with nonsyndromic $\mathrm{CP}$, treated by the Warsaw Cleft Team at the Institute of Mother and Child. In their first years, these children had taken part in a multi-specialization treatment program at the Institute. They all underwent surgery according to the same protocol in their first year. None had any other diagnosed developmental disorders.

The control group comprised children of the same age who were developing normally, selected to match the $\mathrm{CP}$ group with sex, general intelligence $(90<\mathrm{IQ}>129)$, and mother's education. In addition, the researchers tried to make sure that every child with $\mathrm{CP}$ was matched with a child from the same province, living in a locality with a similar population (big city/small town/village). Table 1 presents the two groups' demographics. 
Table 1. Demographics

\begin{tabular}{lcc}
\hline \multicolumn{1}{c}{ Demographic variables } & $\begin{array}{c}\text { Cleft palate group } \\
(\boldsymbol{N}=\mathbf{3 5})\end{array}$ & $\begin{array}{c}\text { Control group } \\
(\boldsymbol{N}=\mathbf{3 5})\end{array}$ \\
\hline Place of residence & 5 & 4 \\
Rural area & 8 & 7 \\
Town with population up to 100,000 & 16 & 18 \\
City with population up to 500,000 & 6 & 6 \\
City with population over 500,000 & & 1 \\
Mother's education & 2 & 8 \\
Elementary & 7 & 25 \\
Vocational & 24 & 1 \\
Secondary & 2 & \\
University & & 12 \\
Sex & 12 & 23 \\
Girl & 23 & 10 \\
Boy & & 15 \\
Age & & \\
6;0-6;11 & & \\
$7 ; 0-7 ; 11$ & 13 & 12 \\
8;0-8;11 & 10 & \\
\hline
\end{tabular}

\section{Research tools}

Metaphor comprehension and interpretation was assessed with the help of the Picture Metaphor Test, Written Metaphor Test, Picture Metaphor Explanation Test, and Written Metaphor Explanation Test from the experimental version of the Right Hemisphere Language Battery (RHLB-PL) for children, designed by Prof. Emilia Łojek, the author of the Polish version of the RHLB for adults (Lojek, 2007). To measure cognitive skills, the Wechsler Intelligence Scale for Children - modified version (WISC-R) was used, in the Polish adaptation of Anna Matczak, Anna Piotrowska, and Wanda Ciarkowska (2008).

The Picture Metaphor Test (PMT) is used to measure ability for abstract thinking based on processing of complex linguistic material. The researcher uses a widely known metaphorical expression in a sentence and then shows the child pictures illustrating the metaphor. The metaphors used in the PMT (the literal translation of metaphors in Polish) are as follows:

1. He was in love and asked for her hand (the meaning of that metaphor in Polish: He asked her to marry him).

2. The police caught a big fish. 
3. She looked like a wet hen (the Polish equivalent of: She looked like a drowned rat).

4. They struck a deal and the house was finally his (the meaning of that metaphor in Polish: They made a deal).

5. Listen, we're going to have a new boss, but keep your mouth padlocked (the Polish equivalent of: Listen, we're going to have a new boss, but zip your mouth).

6. The captain held the soldiers with an iron hand (the Polish equivalent of: The captain managed the soldiers with an iron fist).

7. After a long absence, he returned to his old rubbish heap (the Polish equivalent of: After a long absence, he returned to his old stamping grounds).

8. The woman weighed her words carefully.

9. She had a face like a raspberry (the Polish equivalent of: She had rosy cheeks).

10. After a short conversation, the ice between them was broken.

One of the pictures illustrates the expression's metaphorical meaning, a second picture presents the literal meaning, and a third picture shows an explanation that is too general, inadequate for the metaphor's meaning. Subjects are awarded 1 point for each correct response (total: 10 points). The number of literal and inadequate responses can also be counted. For example, for the metaphor The police caught a big fish, the pictures show: a fish, a big man (fragmentary responses), police officers catching a fish with a fishing pole (literal response), and police officers leading a criminal (metaphorical response).

In the Written Metaphor Test (WMT) also, the researcher uses a widely known metaphorical expression in a sentence and then reads possible explanations of this expression to the child. The metaphors used in the WMT are as follows (the literal translation of metaphors in Polish):

1. Only one of the politicians had clean hands.

2. During his parents' quarrel, Adam found himself between the hammer and the anvil (the Polish equivalent of: During his parents' quarrel Adam was caught between a rock and a hard place).

3. The smart pupil had knowledge of biology in his little finger (the Polish equivalent of: The smart pupil had biology at his fingertips).

4. The salesperson had a good head for business.

5. He received the news of his uncle's death with a heavy heart.

6. John was an excellent reporter and always had his finger on the pulse.

7. The tourist asking for directions was led into raspberries (the Polish equivalent of: The tourist asking for directions was led up the garden path). 
8. Talking with his son, the father did not let his eyes be lathered (the Polish equivalent of: Talking with his son, the father did not let him pull the wool over his eyes).

9. Already on her first day at work Anna was thrown into deep water (the Polish equivalent of: Already on her first day at work Anna was thrown in at the deep end).

10. The soldier intended to complain to the general, but at the last minute he felt his legs were like cotton wool (the Polish equivalent of: The soldier intended to complain to the general, but at the last minute his legs turned to jelly).

Besides a response containing the meaning of the metaphorical expression, subjects are presented with a literal explanation of the metaphor and a general explanation that is inadequate for the metaphor's meaning. Similarly to the PMT, they get 1 point for each correct response (total: 10 points). The number of literal and inadequate responses can also be counted. For example, for the metaphor in the sentence Only one of the politicians had clean hands, three explanations are provided: (1) Only one of the politicians had washed his hands (literal), (2) People should take care to be clean (inadequate), and (3) Only one of the politicians was honest (metaphorical).

The Picture Metaphor Explanation Test (PMET) requires the ability to understand metaphors and express them verbally. Subjects are asked to explain metaphors shown in pictures (the test is based on the metaphorical expressions used in the PMT). Besides the correct response, that is, one that includes the metaphor's abstract meaning, subjects can give a concrete response (literal explanation of the metaphor) or an inadequate one (an explanation that is too general). A subject can also not offer any response at all. A correct response gets 1 point (total: 10 points). The number of incorrect - concrete and abstract (inadequate, too general) - responses is also analyzed.

The Written Metaphor Explanation Test (WMET) also requires the ability to understand metaphors and express them verbally. Subjects are asked to explain metaphors (the test is based on the metaphorical expressions used in the WMT). A correct response includes the abstract meaning of the metaphor, a concrete response invokes the metaphor's literal meaning, and an inadequate response offers an overly general, incorrect explanation. A correct response gets 1 point (total: 10 points). The number of incorrect concrete and abstract responses can also be analyzed.

In the analysis of the PMT and WMT scores, we can distinguish metaphors placed within a certain context (metaphors I, IV, V, VII, and X in the PMT and II, III, V, VI, VII, VIII, IX, and X in the WMT) and ones that lack context (metaphors II, III, VI, VIII, and IX in the PMT and I and IV in the WMT). For example, the pictorial metaphors The police caught a big fish or She looked like a wet hen have no context, while the metaphors Listen, we're going to have a new boss, but keep your mouth padlocked or They struck a deal and the house 
was finally his include additional information placing them in context. Most of the written metaphors include an added explanation, for example, The soldier intended to complain to the general, but at the last minute he felt his legs were like cotton wool. This group also includes metaphors without any added context: Only one of the politicians had clean hands or The salesperson had a good head for business.

\section{Procedure}

The project was approved by the Ethics Committee of the Faculty of Psychology, University of Warsaw, prior to recruiting participants.

Information about the study was spread among families with CP children through the Institute of Mother and Child in Warsaw. Parents who agreed to be contacted received written information about the study's aim and design. At this stage, the parents of 216 children were contacted, and from among them, 43 children were ultimately qualified for the study, as meeting the criteria of age, cleft type, and lack of diagnosis of other developmental disorders. In the end, eight children from this group did not take part in the study due to the presence of other health or development issues, that is, hearing impairments, heart problems, postoperative complications, and confirmed dyslexia. Parents of typically developing children were contacted through generally accessible schools.

\section{Results}

Before analyzing the level of metaphor comprehension and interpretation, the study groups were compared for general intelligence and different cognitive skills measured with the WISC-R test. The Full Scale IQ variable had a normal distribution in both groups, and the condition of equality of variance measured with Levene's test was also fulfilled, $F(1,68)=.008 ; p>.05$, so variance analysis was used to compare the means in the groups. The descriptive statistics and analysis results are presented in Table 2.

Table 2. Descriptive Statistics for the Full Scale IQ Variable

\begin{tabular}{lcccc}
\hline \multicolumn{1}{c}{ Group } & Minimum & Maximum & $\boldsymbol{M}$ & $\boldsymbol{S D}$ \\
\hline Cleft palate $(\mathrm{N}=35)$ & 91 & 124 & 109.57 & 8.19 \\
Control $(\mathrm{N}=35)$ & 99 & 125 & 111.29 & 7.19 \\
\hline Note. $M=$ mean; $S D=$ standard deviation &
\end{tabular}

No statistically significant differences were found between the groups in Full Scale IQ. Comparisons were also made for the Verbal and Performance IQ as well as the derived scores in the WISC-R tests. The descriptive statistics for the variables in question are presented in Table 3. 
Table 3. Descriptive Statistics for Verbal and Nonverbal IQ and Derived Scores in WISC-R Tests in the group of Children with Cleft Palate $(N=35)$ and the Control Group $(N=35)$

\begin{tabular}{lcccc}
\hline \multirow{2}{*}{ Variables } & \multicolumn{2}{c}{ Cleft palate group } & \multicolumn{2}{c}{ Control group } \\
\cline { 2 - 5 } & $\boldsymbol{M}$ & $\boldsymbol{S D}$ & $\boldsymbol{M}$ & $\boldsymbol{S D}$ \\
\hline Verbal IQ & 101.43 & 12.394 & 107.11 & 7.012 \\
Performance IQ & 115.77 & 7.051 & 113.63 & 8.732 \\
Information & 10.49 & 2.759 & 11.06 & 2.91 \\
Vocabulary & 9.4 & 2.82 & 11.63 & 2.045 \\
Comprehension & 10.14 & 2.102 & 11.66 & 1.714 \\
Block Design & 12.4 & 1.818 & 12.03 & 2.407 \\
Coding & 12.46 & 1.868 & 11.94 & 2.326 \\
Mazes & 11.17 & 1.671 & 11.83 & 2.216 \\
Similarities & 11.17 & 1.671 & 11.83 & 2.216 \\
Arithmetic & 11 & 3.413 & 10.63 & 2.377 \\
Digit Span & 9.14 & 2.255 & 10.09 & 2.306 \\
Picture Completion & 11.63 & 2.498 & 12.11 & 2.816 \\
Picture Arrangement & 12.17 & 2.294 & 11.89 & 1.922 \\
Object Assembly & 12.17 & 2.294 & 11.37 & 2.276 \\
\hline Note. M & & & &
\end{tabular}

Note. $M=$ mean; $S D=$ standard deviation

A one-factor analysis of variance ( $\mathrm{CP}$ children vs. control group) showed that the means differed significantly for the following variables:

- Verbal IQ - the cleft palate group had significantly lower scores than the control group, $F(1,68)=5.580 ; p=.021 ; \eta^{2}=.076$;

- derived score in the Vocabulary test - the cleft palate group had significantly lower scores than the control group, $F(1,68)=14.325 ; p<.001 ; \eta^{2}=.174$;

- derived score in the Comprehension test - the cleft palate group had significantly lower scores than the control group, $F(1,68)=10.907$; $p=.002 ; \eta^{2}=.138$.

The derived scores in the other WISC-R tests did not show differences between the groups. Next, inter- and intragroup analyses were performed on the raw scores of the subjects in the Picture Metaphor Test, Written Metaphor Test, Picture Metaphor Explanation Test, and Written Metaphor Explanation Test. The number of different mistakes made by the subjects was compared as well, and the level of difficulty of the tasks in the WMT and PMT was checked.

\section{Comparison of Metaphor Comprehension and Interpretation in the Cleft Palate Group and the Control Group}

The distribution of the WMET scores was normal, and the condition of equality of variance was also fulfilled $(F=3.101 ; p>.05)$, therefore, a one-factor analysis of variance was applied. The other comparisons were 
performed using the nonparametric Mann-Whitney $U$ test for independent samples. Table 4 presents the descriptive statistics for the variables in question.

Table 4. Descriptive Statistics for Overall Scores in RHLB-PL Battery Tests in the Group of Children with Cleft Palate $(N=35)$ and the Control Group $(N=35)$

\begin{tabular}{lcccc}
\hline \multirow{2}{*}{ Test } & \multicolumn{2}{c}{ Cleft palate group } & \multicolumn{2}{c}{ Control group } \\
\cline { 2 - 5 } & $\boldsymbol{M}$ & $\boldsymbol{S D}$ & $\boldsymbol{M}$ & $\boldsymbol{S D}$ \\
\hline PMT & 5.54 & 1.651 & 5.80 & 1.694 \\
WMT & 5.89 & 1.795 & 6.51 & 2.077 \\
PMET & 3.09 & 1.442 & 4.49 & 1.946 \\
WMET & 3.23 & 1.457 & 4.63 & 2.059 \\
\hline
\end{tabular}

Note. PMT - Picture Metaphor Test, WMT - Written Metaphor Test, PMET - Picture Metaphor Explanation Test, WMET - Written Metaphor Explanation Test; M - mean; $S D$ - standard deviation

The one-factor analysis of variance (CP group vs control group) showed that the means differed in a statistically significant way in the case of the WMET overall result - the CP group had lower scores than the control group, $F(1,68)=11.692 ; p<.001 ; \eta^{2}=.147$. Moreover, the CP group achieved significantly lower scores than the control group in the PMET, $(Z=-3.040$; $p=.002 ; d=.806)$. In the case of overall scores in the PMT and WMT, no statistically significant differences were noted between the groups.

\section{Comparison of Mistakes Made by Children from the CP Group and the Control Group in the Metaphor Tests}

The two groups were compared for the number of incorrect and correct responses, as well as the number of different types of mistake in the PMT, WMT, PMET, and WMET. The distribution of the relevant variables was different than normal, so the Mann-Whitney $U$ test was used in the analyses. The descriptive statistics for the number of fragmentary, literal, and inadequate responses in the PMT and WMT are shown in Table 5.

No statistically significant differences were found between the two groups for the number of literal responses in the PMT, the number of fragmentary responses in the PMT, the number of literal responses in the WMT, and the number of inadequate responses in the WMT.

Based on the subjects' responses in the PMET and WMET, the following were also calculated: the number of all responses (incorrect and correct), the percentage of concrete mistakes (the share of concrete incorrect responses in the number of responses), and the percentage of abstract mistakes (the share of abstract incorrect responses in the number of responses). The descriptive statistics for the variables in question are presented in Table 6. 
Table 5. Descriptive Statistics for the Number of Literal and Fragmentary Responses in the PMT and Literal and Inadequate Responses in the WMT in the Group of Children with Cleft Palate and the Control Group

\begin{tabular}{cccccc}
\hline Group & & $\begin{array}{c}\text { Number of } \\
\text { literal } \\
\text { responses } \\
\text { in the PMT }\end{array}$ & $\begin{array}{c}\text { Number of } \\
\text { fragmentary } \\
\text { responses } \\
\text { in the PMT }\end{array}$ & $\begin{array}{c}\text { Number of } \\
\text { literal } \\
\text { responses } \\
\text { in the WMT }\end{array}$ & $\begin{array}{c}\text { Number of } \\
\text { inadequate } \\
\text { responses } \\
\text { in the WMT }\end{array}$ \\
\hline Cleft palate & $M$ & 2.37 & 2.46 & 2.57 & 1.57 \\
$(N=35)$ & $S D$ & 1.437 & 1.559 & 1.399 & 1.313 \\
& $M e$ & 2.0 & 2.0 & 2.0 & 1.0 \\
Control & $M$ & 2.51 & 1.89 & 2.06 & 1.46 \\
$(N=35)$ & $S D$ & 1.563 & 1.022 & 1.392 & 1.067 \\
& $M e$ & 2.0 & 2.0 & 2.0 & 1.0 \\
\hline
\end{tabular}

Note. $M=$ mean; $S D=$ standard deviation; $M e=$ median

Table 6. Descriptive Statistics for the Number of Responses in the PMET and WMET in the Group of Children with Cleft Palate and the Control Group

\begin{tabular}{lccccccc}
\hline \multirow{2}{*}{ Variable } & \multicolumn{3}{c}{$\begin{array}{c}\text { Cleft palate group } \\
(\mathbf{N}=\mathbf{3 5})\end{array}$} & \multicolumn{3}{c}{$\begin{array}{c}\text { Control group } \\
(\mathbf{N}=\mathbf{3 5})\end{array}$} \\
\cline { 2 - 8 } & $\boldsymbol{M}$ & $\boldsymbol{S D}$ & $\boldsymbol{M e}$ & $\boldsymbol{M}$ & $\boldsymbol{S D}$ & $\boldsymbol{M e}$ \\
\hline Number of responses in the PMET & 3.7 & 1.7 & 3 & 4.3 & 1.5 & 4 \\
Number of responses in the WMET & 7.5 & 1.6 & 8 & 7.5 & 1.7 & 8 \\
\hline
\end{tabular}

Note. $M=$ mean; $S D=$ standard deviation; $M e=$ median

In both the PMET $(Z=-6.398 ; p<.001 ; d=-2.312)$ and the WMET $(Z=-6.013 ; p<.001 ; d=-1.994)$, children with CP gave fewer responses than children from the control group.

The descriptive statistics for the variables of percentage of concrete and abstract mistakes in the PMET and WMET are presented in Table 7.

Table 7. Descriptive Statistics for the Percentage of Concrete and Abstract Mistakes in the PMET and WMET in the Group of Children with Cleft Palate and the Control Group

\begin{tabular}{cccccc}
\hline Group & & $\begin{array}{c}\text { Percent of } \\
\text { concrete } \\
\text { mistakes } \\
\text { PMET }\end{array}$ & $\begin{array}{c}\text { Percent of } \\
\text { abstract } \\
\text { mistakes } \\
\text { PMET }\end{array}$ & $\begin{array}{c}\text { Percent of } \\
\text { concrete } \\
\text { mistakes } \\
\text { WMET }\end{array}$ & $\begin{array}{c}\text { Percent of } \\
\text { abstract } \\
\text { mistakes } \\
\text { WMET }\end{array}$ \\
\hline \multirow{2}{\text{Cleftpalate}}{} & $M$ & .11 & .3 & .24 & .19 \\
$(N=35)$ & $S D$ & .21 & .9 & .28 & .31 \\
& $M e$ & .0 & .0 & .20 & .0 \\
Control & $M$ & .26 & .15 & .26 & .15 \\
$(N=35)$ & $S D$ & .19 & .11 & .22 & .13 \\
& $M e$ & .25 & .14 & .25 & .17 \\
\hline
\end{tabular}

Note. $M=$ mean; $S D=$ standard deviation; $M e=$ median 
In the PMET, CP children made fewer concrete mistakes $(Z=-3.933$; $p<.001 ; d=-.767)$ and fewer abstract mistakes $(Z=-4.873 ; p<.001$; $d=-1.189)$ than children from the control group. In the WMET, the differences between the groups for the percentage of concrete and abstract mistakes were not statistically significant.

\section{Intragroup Comparison of Comprehension and Interpretation of Pictorial and Written Metaphors}

The Wilcoxon signed-rank test for dependent samples did not reveal differences in performance in the PMT and WMT nor in the PMET and WMET in the CP group. Meanwhile, there were statistically significant differences in performance in the tests for understanding and explaining metaphors. Children with CP had better scores in the PMT than in the PMET $(Z=4.966 ; p<.001)$ and in the WMT than in the WMET $(Z=5.130 ; p<.001)$. In the control group, besides differences between PMT and PMET performance $(Z=4.042$; $p<.001)$ and WMT and WMET performance $(Z=4.942 ; p<.001)$, there were also statistically significant differences between the scores in the WMT (higher score $)$ and the PMT $(Z=2.225 ; p=.026)$.

\section{Comparison of the difficulty of the different metaphors}

The research material comprised 20 metaphors: 10 in the PMT (and then in the PMET) and another 10 in the WMT (and WMET). The percentages of correct responses in the different tests are shown in Figure 1.
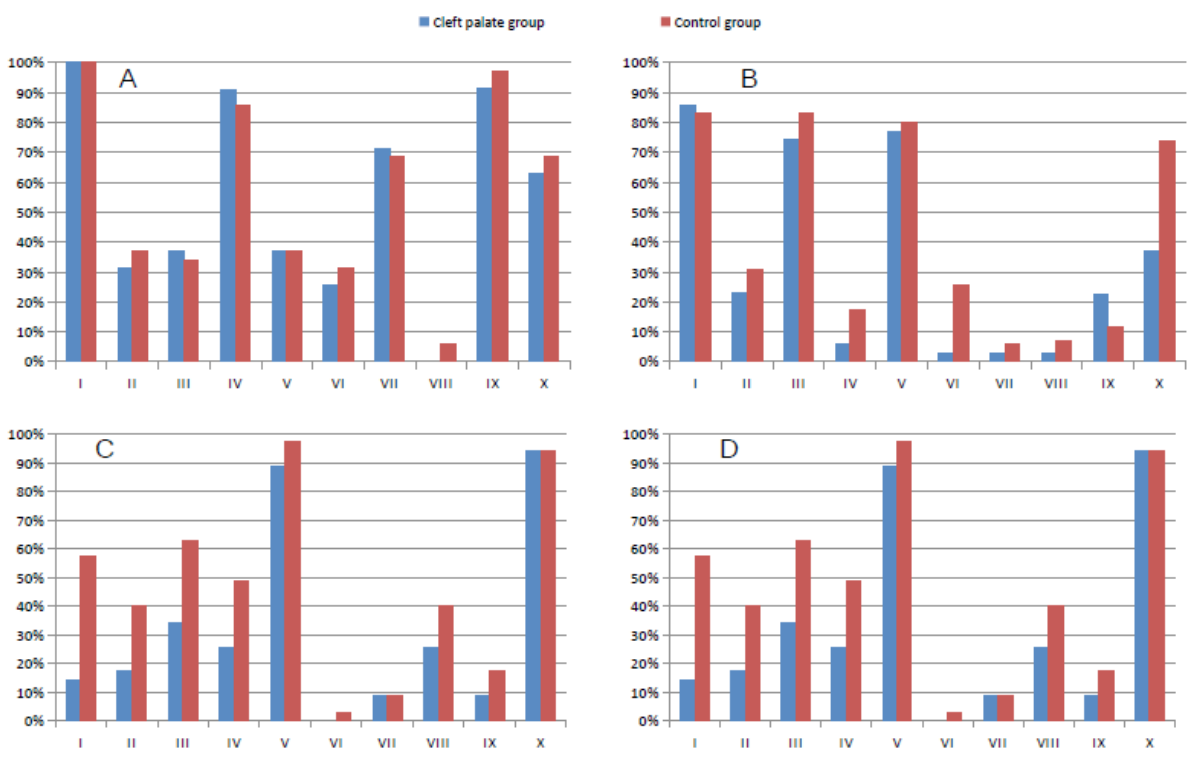

Figure 1. Correct response percentage for successive metaphors in: A - Picture Metaphor Test, B - Picture Metaphor Explanation Test, C - Written Metaphor Test, and D - Written Metaphor Explanation Test. 
To assess whether the level of difficulty of the tests was different for the two groups, the Chi-squared statistic was used. The results were not statistically significant for the PMT and WMP. In the PMET, statistically significant differences between the groups appeared for Metaphor VI: The captain held the soldiers with an iron hand, $\chi^{2}(1, N=70)=10.057, p=.002$, Cramér's $V=.379$, and Metaphor X: After a short conversation, the ice between them was broken, $\chi^{2}(1, N=70)=9.785, p=.002$, Cramér's $V=.374$. In the WMET tasks, the groups differed significantly for Metaphor I: Only one of the politicians had clean hands, $\chi^{2}(1, N=70)=14.057, p<.001$, Cramér's $V=.447$, Metaphor II: During his parents' quarrel, Adam found himself between the hammer and the anvil, $\chi^{2}(1, N=70)=4.485, p=.034$, Cramér's $V=.253$, and Metaphor III: The smart pupil had knowledge of biology in his little finger, $\chi^{2}(1, N=70)=5.719, p=.017$, Cramér's $V=.286$.

The analysis showed that the subjects in both groups gave more correct responses in tasks involving metaphors in context. There were over $80 \%$ correct responses for Metaphors I and IV in the PMT (respectively: He was in love and asked for her hand and They struck a deal and the house was finally his), over $60 \%$ correct responses for Metaphors VII and X in the PMT (After a long absence, he returned to his old rubbish heap and After a short conversation, the ice between them was broken), and over $90 \%$ correct responses for Metaphors V and X in the WMT (He received the news of his uncle's death with a heavy heart and The soldier intended to complain to the general, but at the last minute he felt his legs were like cotton wool). It was similar in the case of explaining the metaphors. The greatest number of subjects correctly explained Metaphors I, V, and X in the PMT and V and X in the WMT. Metaphor III in the PMT (She looked like $a$ wet hen) was an exception, because in both groups it was recognized more poorly in the illustration than it was explained. It was also observed that for Metaphors II, III, V, and VI in the PMT and I and VII in the WMT, close to $90 \%$ of incorrect responses in both groups were literal responses. In the case of Metaphors IV and VII in the WMT, over $90 \%$ of mistakes were fragmentary responses.

\section{Discussion}

A comparison of metaphor comprehension and interpretation between $\mathrm{CP}$ children and typically developing children showed no statistically significant intergroup differences for metaphor comprehension. However, such differences did occur for explaining of metaphors. Children with cleft palate had lower scores than the control group in both the WMET and the PMET. It needs mentioning that these tests were harder for both groups than the metaphor comprehension tests.

Interpreting the above results, one needs to consider the number of all responses given by the children, correct and incorrect, as well as the type of 
mistakes made. Cleft palate children gave fewer (correct and incorrect) responses overall. In the WMT and the PMT, subjects from this group gave correct responses to the same extent as the control group, which means their level of understanding of the metaphors' meaning was similar. Generating an explanation caused them problems, however. Such a result is compatible with the cleft palate children's behavior during the study: They produced few spontaneous utterances and sometimes stopped themselves from answering, despite their positive attitude toward the researcher and the study itself. Similar limitations in communicative competence have been shown in studies involving cleft palate children of preschool age. They produced fewer assertive utterances than their typically developing peers, gave less adequate responses to commentaries, and did not start new themes expanding the subject of a conversation (Frederickson et al., 2006). By comparison, a study of early school-aged children with attention deficit hyperactivity disorder (ADHD) with the adult version of the RHLB-PL Battery did not reveal any difficulties with linguistic functions (Jędrzejowska \& Borkowska, 2011). Children with ADHD only did worse than their peers in the PMT, which the authors associated with difficulties concentrating their attention on the visual spatial material. Hence, cleft palate children's withdrawal from verbal activity during task interaction is likely a characteristic element of their functioning, observed at preschool as well as early school age. This could indicate some kind of general difficulty with communication and social relations that is certainly worth taking into account in the process of supporting the development of this group of children.

When considering the intergroup differences described above, it is worth noting that the scores of the $\mathrm{CP}$ children in the Vocabulary and Comprehension tests in the WISC-R were lower than those of the control group. This is in good agreement with the results, among others, of Conrad et al. (2009), in whose study, children with $\mathrm{CP}$ had lower scoresin language skills than the control group, and their verbal skills were worse than their nonverbal skills. Analyzing the scores of the subjects in those tests, the authors pointed not only to the skills that are necessary for solving specific tasks, but also to the ability to communicate responses. This analysis suggests that children with $\mathrm{CP}$ could have special problems with generating responses. However, the Information and Arithmetic tests, in which the subjects also had to generate replies, were performed just as well by both groups in the study. This could suggest that producing a response is not hard for $\mathrm{CP}$ children when they have to use their memory resources and acquired knowledge, but becomes a problem when they have to use their vocabulary resources, building and updating concepts or definitions. It is possible, therefore, that CP children's difficulties are not related to processing or understanding figurative language but, more generally, to language use, especially when they are required to produce more complex statements. It is not out of the question, however, that the lower scores in the Vocabulary and Comprehension tests were 
related to emotional factors: the children held back or gave laconic responses that were insufficient for achieving better scores in the tests.

The present study also compared performance in tasks involving metaphors presented in pictures or verbally. In the PMT, the pictures illustrating possible responses were available to the subjects when they were choosing their responses, whereas the WMT included "performance limitations" (cf. Białecka-Pikul, 2002): The responses were read out, which meant the children had to involve their operating memory. It was found, however, that the way the responses were presented - as pictures or utterances - did not affect task performance. This is compatible with the results of a study on children of a similar age conducted by Kogan and Chadrow (1986).

On the other hand, differences in performance were observed in tasks containing metaphors with or without a context. In both groups, the subjects gave more correct responses on the meaning of metaphors when a context was provided. It was the same also for explaining metaphors. This is in good agreement with the results of earlier research showing the importance of context in understanding figurative language (Cain, Oakhill, \& Lemon, 2005; Cain et al., 2009). Some researchers believe it is context that gives a metaphor its meaning (cf. Leddy, 1983). Metaphors without context could be perceived as direct, literal messages. The results of the present study could support this claim, since it was observed that for Metaphors II, III and VI from the PMT (respectively: The police caught a big fish, She looked like a wet hen, and The captain held the soldiers with an iron hand) and I from the WMT (Only one of the politicians had clean hands), almost $90 \%$ of the incorrect responses in both groups were literal responses. The pictures showed police officers catching a big fish with a fishing pole, a wet hen, and a captain holding soldiers with an iron hand, and besides the instruction at the start of the task, there was nothing to suggest a metaphorical meaning of the sentences. Therefore, if a metaphor was not placed within a context and the literal meaning made some kind of sense, the children's interpretation was literal. This could support the hypothesis offered by Searle (1979) that we search for literal explanations first, and only when they are inappropriate do we seek metaphorical meanings.

It is also interesting that insofar as the pictorial metaphors in which literal explanations were given were explained very well (Metaphor III and V from the PMT), pictorial metaphors less familiar to the subjects, for which they made fragmentary mistakes, were also explained incorrectly or were not explained at all (Metaphor IV and VIII). Thus, if the literal meaning made no sense (e.g. the picture of a woman weighing series of letters for the metaphor The woman weighed her words carefully) and understanding the metaphorical meaning was beyond the child's capacity, the subjects concentrated on individual words, choosing a response that referred to a fragment of the expression (words, woman, scales). Another argument supporting the hypothesis that context plays a major role in metaphor interpretation is the fact that children from the control 
group did better in the WMT than in the PMT, while it was in the latter test that most of the metaphors were given context.

It is also important for interpreting the results that all the metaphors used in the study are "dead" metaphors (cf. Davidson, 1978; Ricoeur, 1984), that is, conventional ones that have long been in widespread use and have become a part of our vocabulary. This means that understanding and explaining them could largely depend on a person's linguistic experience. The importance of linguistic experience has been highlighted in other works (Gentner, 1977), as have the relationships between figurative language comprehension and knowledge (Nippold, Moran, \& Schwarz, 2001).

The study presented here provided information on how children with $\mathrm{CP}$ function at early school age in a previously unexplored area. However, the study had some limitations, the most important of them being the small number of participants. This was due to the narrowly defined criteria for selecting the subjects, aimed at creating a uniform group and avoiding the influence of other factors on the results: the age range and intelligence level, type of cleft, identical treatment protocol, the lack of concomitant defects and disorders. However, the small number of subjects made it impossible to conduct statistical analyses for subgroups, for example, taking into account the subjects' sex. Moreover, the project would have provided some particularly valuable information if the study had been a prospective one in which data on CP children's linguistic functions had been gathered from their birth, including observations of preverbal behaviors, parent-child interactions and detailed information on applied interventions and methods to support the children's development.

\section{Acknowledgments}

The authors wish to thank all the children taking part in the study as well as their parents. Thanks also go to the Warsaw Cleft Team at the Institute of Mother and Child for helping contact parents. We would like to express our gratitude to Professor Karen Bryan for her valuable comments. We are also extremely grateful to Professor Barbara Bokus for preparing the English version of the present paper.

\section{References}

Bee, H. (2004). Psychologia rozwoju człowieka [Polish translation of Lifespan Development, transl. A. Wojciechowski]. Poznań: Zysk i Spółka.

Białecka-Pikul, M. (2002). Co dzieci wiedza o umyśle i myśleniu: badania i opis dziecięcej reprezentacji stanów mentalnych [What children know about the mind and thinking: Studies and report on children's representations of mental states]. Kraków: Wydawnictwo Uniwersytetu Jagiellońskiego. 
Białecka-Pikul, M. (2012). Narodziny i rozwój refleksji nad myśleniem [The birth and development of reflection on thinking]. Kraków: Wydawnictwo Uniwersytetu Jagiellońskiego.

Biela, A. (1981). Psychologiczne podstawy wnioskowania przez analogie [Psychological foundations of reasoning by analogy]. Warszawa: Państwowe Wydawnictwo Naukowe.

Bjorklund, D. (2005). Children's Thinking. Belmont: CA. Wadsworth/Thomson Learning.

Brunnegård, K., \& Lohmander, A. (2007). A cross-sectional study of speech in 10-year-old children with cleft palate: Results and issues of raters reliability. The Cleft Palate - Craniofacial Journal, 44(1), 33-44. doi: 10.1597/05-164

Bryan, K.L. (2007). Bateria do Oceny Funkcji Językowych Prawej Półkuli Mózgu [Polish translation of Right Hemisphere Language Battery]. Warszawa: Pracownia Testów Psychologicznych.

Cain, K., Oakhill, J., \& Lemmon, K. (2005). The relation between children's reading comprehension level and their comprehension of idioms. Journal of Experimental Psychology, 90, 65-87. doi: 10.1016/j.jecp.2004.09.003

Cain, K., Towse, A. S., \& Knight, R. S. (2009). The development of idiom comprehension: An investigation of semantic and contextual processing skills. Journal of Experimental Child Psychology, 102, 280-298. doi: 10.1016/j.jecp.2008.08.001

Chapman, K. L. (2011). The relationship between early reading skills and speech and language performance in young children with cleft lip and palate. The Cleft Palate-Craniofacial Journal, 48(3), 301-311. doi: 10.1597/08-213

Chapman, K.L., Hardin-Jones, M., \& Halter, K.A. (2003). The relationship between early speech and later speech and language performance for children with cleft lip and palate. Clinical Linguistics \& Phonetics, 17, 173-197. doi: 10.1080/0269920021000047864

Chapman, K. L., Hardin-Jones, M., Schulte, J., and Halter, K. A. (2001). Vocal development of 9-month-old babies with cleft palate. Journal of Speech, Language and Hearing Research, 44(6), 1268-1283. doi: 10.1044/10924388(2001/099)

Collett, B. R., Leroux, B., \& Speltz, M. L. (2010). Language and early reading among children with orofacial clefts. The Cleft Palate-Craniofacial Journal, 47(3), 284-292. doi: 10.1597/08-172.1

Collett, B. R., Keich Cloonan, Y., Speltz, M.L., Anderka, M., \& Werler, M. M. (2012). Psychosocial functioning in children with and without orofacial clefts and their parents. The Cleft Palate-Craniofacial Journal, 49(4), 397405. doi: 10.1597/10-007

Conrad, A. L., Richman, L., Nopoulos, P., \& Dailey, S. (2009). Neuropsychological functioning in children with non-syndromic cleft of the lip and/or palate. Child Neuropsychology, 15, 471-484. doi: 10.1080/09297040802691120 
Curran, T., \& Doyle, J. (2011). Picture superiority doubly dissociates the ERP correlates of recollection and familiarity. Journal of Cognitive Neuroscience, 23(5), 1247-1262. doi: 10.1162/jocn.2010.21464

Davidson, D. (1978). What metaphors mean. Critical Inquiry, 5, 31-47.

Defetyer, M. A., Russo, R., \& McPartlin, P. L. (2009). The picture superiority effect in recognition memory: A developmental study using the response signal procedure. Cognitive Development, 24, 265-273. doi: 10.1016/j. cogdev.2009.05.002

Dobrzyńska, T. (2012). Od stowa do sensu. Studia o metaforze [From word to meaning. Studies on metaphor]. Warszawa: Wydawnictwo Instytutu Badań Literackich PAN.

Dudkiewicz, Z. (1997). Rozszczep wargi i podniebienia w świetle współczesnych poglądów [Cleft lip and palate in the light of contemporary views]. Medycyna Wieku Rozwojowego, 1, 667-679.

Feragen, K., Særvold, K., Aukner, R., \& Stock, N. (2017). Speech, language, and reading in 10-year-olds with cleft: Associations with teasing, satisfaction with speech, and psychological adjustment. The Cleft Palate-Craniofacial Journal, 54(2), 153-165. doi: 10.1597/14-242. doi: 10.1597/14-242

Frederickson, M. S., Chapman, K., \& Hardin-Jones, M. (2006). Conversational skills of children with cleft lip and palate: A replication and extension. The Cleft Palate-Craniofacial Journal, 43(2), 179-187.

Gentner, D. (1977). Children's performance on a spatial analogies task. Child Development, 48, 1034-1039. doi: 10.1597/04-086.1

Goldstein, M. H., Schwade, J. A., \& Bornstein, M. H. (2009). The value of vocalizing: Five-month-old infants associate their own noncry vocalizations with responses from caregivers. Child Development, 80(3), 636-644. doi: 10.1111/j.1467-8624.2009.01287.x

Happé F., \& Loth, E. (2002). Theory of mind and tracking speakers' intentions. Mind \& Language, 17(1-2), 24-36. doi: 10.1111/1468-0017.00187

Hardin-Jones, M., \& Chapman, K. L. (2014). Early lexical characteristics of toddlers with cleft lip and palate. The Cleft Palate-Craniofacial Journal, 51(6), 622-631. doi: 10.1597/13-076

Jędrzejowska, N., \& Borkowska, A. (2011). Prawopółkulowa komunikacja językowa a funkcjonowanie intelektualne u dzieci z ADHD [Right hemisphere language communication and intellectual functions in children with ADHD]. Psychiatria i Psychologia Kliniczna, 11(2), 72-82.

Jones, M. C. (1988). Etiology of facial clefts: Prospective evaluation of 428 patients. The Cleft Palate-Craniofacial Journal, 25(1), 16-20.

Kogan, N., \& Chadrow, M. (1986). Children's comprehension of metaphor in the pictorial and verbal modality. International Journal of Behavioral Development, 9(3), 285-295. 
Konopka, K. (2017). Trudności w ekspresji mowy a zdolności intelektualne $i$ kompetencja komunikacyjna - analiza wybranych aspektów funkcjonowania poznawczego dzieci z rozszczepami podniebienia [Difficulties with speech production versus intellectual capacity and communicative competence: an analysis of selected aspects of cleft palate children's cognitive functions]. Unpublished doctoral dissertation supervised by Ewa Pisula. Faculty of Psychology, University of Warsaw.

Kubicka, D. (2005). Myślenie metaforyczne i jego uwarunkowania u dzieci w wieku od 4 do 10 lat [Metaphorical thinking and its determinants in children aged from 4 to 10]. Studia Psychologiczne, 43(2), 59-73.

Kuehn, D., \& Moller, K. (2000). Speech and language issues in the cleft palate population: The state of the art. The Cleft Palate-Craniofacial Journal, 37(4), 348-383. doi: 10.1597/1545-1569(2000)037<0348:SALIIT>2.3.CO;2

Kuhl, P. K., \& Meltzoff, A. N. (1996). Infant vocalizations in response to speech: Vocal imitation and developmental change. The Journal of Acoustical Society of America, 100, 2425-2438. doi: 10.1121/1.417959

Leddy, T. (1983). Davidson's Rejection of Metaphorical Meaning. Philosophy and Rhetoric, 16(2), 63-78.

Leslie, A. M. (1994). Pretending and believing: Issues in the theory of ToMM. Cognition, 50, 211-238. doi: 10.1016/0010-0277(94)90029-9

Łobacz, P. (2005). Prawidłowy rozwój mowy dziecka [Normal speech development in children]. In T. Gałkowski, E. Szeląg and G. Jastrzębowska (eds.), Podstawy neurologopedii. Podręcznik akademicki [Rudiments of neurological speech therapy. University textbook] (pp. 231-268). Opole: Uniwersytet Opolski.

Łojek,E.(2007).BateriaTestówdoBadaniaFunkcjiJęzykowychiKomunikacyjnych Prawej Pótkuli Mózgu (RHLB-PL) [Right Hemisphere Language and Communication Battery of Tests (RHLB-PL)]. Warszawa: Pracownia Testów Psychologicznych Polskiego Towarzystwa Psychologicznego.

Matczak, A., Piotrowska, A., \& Ciarkowska, (2008). Skala inteligencji D. Wechslera dla dzieci - wersja zmodyfikowana (WISC-R) Podręcznik [Wechsler Intelligence Scale for Children - modified version (WISC-R). Textbook]. Warszawa: Pracownia Testów Psychologicznych Polskiego Towarzystwa Psychologicznego.

Nippold, M. A., Moran, C., \& Schwarz, I. E. (2001). Idiom understanding in preadolescents: Synergy in action. American Journal of Speech-Language Pathology, 10(2), 169-179. doi: 10.1044/1058-0360(2001/016)

Norbury, C. F. (2005). The relationship between theory of mind and metaphor: Evidence from children with language impairment and autistic spectrum disorder. British Journal of Developmental Psychology, 23(3), 383-399. doi: $10.1348 / 026151005 X 26732$ 
Oller, D. K., Eilers, R. E., Neal, A. R., \& Schwartz, H. K. (1999). Precursors to speech in infancy: the prediction of speech and language disorders. Journal of Communication Disorders, 32(4), 223-245. doi: 10.1016/S00219924(99)00013-1

Özçaliskan, S. (2005). On learning to draw the distinction between physical and metaphorical motion: Is metaphor an early emerging cognitive and linguistic capacity? Journal of Child Language, 32, 291-318. doi: 10.1017/ S0305000905006884

Piaget, J. (1954). The construction of reality in the child. New York, NY: Basic Books.

Pluta-Wojciechowska, D. (2010). Podstawy patofonetyki mowy rozszczepowej [Rudiments of the pathophonetics of cleft speech]. Bytom: Wydawnictwo Ergo-Sum.

Ricoeur, P. (1984). Proces metaforyczny jako poznanie, wyobrażanie i odczuwanie [Polish translation of The Metaphorical Process as Cognition, Imagination, and Feeling]. Pamiętnik Literacki, 75(2), 269-287.

Richman, L. C., Eliason, M. J., \& Lindgren, S. D. (1988). Reading disability in children with clefts. The Cleft Palate-Craniofacial Journal, 25, 21-25.

Richman, L. C., \& Nopoulos, P. (2009). Neuropsychological and neuroimaging aspects of cleft lip and palate. In: J. E. Losee, R. E. Kirschner (Eds.), Comprehensive Cleft Care (pp. 991-1000). New York, NY: McGraw-Hill Education.

Richman, L. C., Wilgenbusch, T., \& Hall, T. (2005). Spontaneous verbal labeling: Visual memory and reading ability in children with cleft. The Cleft PalateCraniofacial Journal, 42, 565-569. doi: 10.1597/04-128R.1

Qualls, C. D., O’Brien, R. M., Blood, G. W., \& Hammer, C. S. (2003). Contextual variation, familiarity, academic literacy, and rural adolescents' idiom knowledge. Language, Speech, \& Hearing Services in Schools, 34, 69-79. doi: 10.1044/0161-1461

Searle, J. (1979). Metaphor. In A. Ortony (Ed.), Metaphor and Thought (pp. 83-112). Cambridge: Cambridge University Press.

Stoel-Gammon, C. (2011). Relationships between lexical and phonological development in young children. Journal of Pediatric Psychology, 25, 85-90. doi: $10.1017 / \mathrm{S} 0305000910000425$

Warlaumont, A. S., Oller, D. K., Buder, E. H., Dale, R., \& Kozma, R. (2010). Data-driven automated acoustic analysis of human infant vocalizations using neural network tools. Journal of the Acoustical Society of America, 127(4), 2563-2577. doi: 10.1121/1.3327460

Weinrich, H. (1981). Ogólna semantyka metafory [Polish translation of Semantik der Metapher, transl. M. Łukasiewicz]. Teksty: teoria literatury, krytyka, interpretacja, 3(57), 61-75.

Vihman, M. M. (1993). Variable paths to early word production. Journal of Phonetics, 21, 61-82. 
Vihman, M.M. (1996). Phonological Development: The Origins of Language in the Child. Cambridge, MA: Blackwell.

Vosniadou, S., \& Schommer, M. (1988). Explanatory analogies can help children acquire information from expository text. Journal of Educational Psychology, 80(4), 524-536. doi: 10.1037/0022-0663.80.4.524

Wen, Y., \& Lu, Q. (2015). Risk prediction models for oral clefts allowing for phenotypical heterogeneity. Frontiers in Genetics, 6, 264-272. doi: 10.3389/ fgene.2015.00264 